\title{
STRUCTURE, CONTEXT AND MEANING IN THE SAMUEL CONCLUSION (2 SA. 21-24) ${ }^{1}$
}

\author{
Herbert H. Klement
}

In recent years increased attention has been devoted to the narratives of the books of Samuel. This newer interest in these books has concentrated especially on narrative technique and the type of literary portrayal found in these accounts. The peculiar nature of the concluding chapters of Samuel with its six chiastically arranged units has seldom been the object of an independent study. Nonetheless it is this more recent interest in literary forms which has increased awareness of the boundaries of literary units, and thus of the significance of beginnings and endings in determining the interpretation of those units. This study seeks, therefore, within the framework of a literary enquiry, to understand the chapters 2 Samuel 2124 in their function as the conclusion of the Samuel corpus.

To this end an opening chapter gives an overview of the main trends in the interpretation of this group of texts in the last two centuries. It was the biographical interest in brilliant personalities characteristic of the era of Romanticism that started to have a decisive influence on the exegesis of stories about David as a history-forming personality. 1 Kings 1-2 (describing the events surrounding David's death) has been felt since then to be an essential part of David's 'biography'. The current state of research is characterised on the one hand by a great multitude of different approaches, with no particular direction of research predominating, and on the other hand by a trend towards mainly synchronic literary interpretations. This latter trend forms the starting-point for the fresh investigation being undertaken in this study.

\footnotetext{
${ }^{1}$ Herbert H. Klement, 2 Samuel 21-24: Structure, Context and Meaning in the Samuel Conclusion (unpublished Ph.D. Thesis, University of Coventry/Wycliffe Hall, Oxford 1995); supervisors: Dr. J.G. McConville; Prof. R.P. Gordon).
} 
The second chapter investigates the connections of the Samuel Conclusion with the rest of the Samuel corpus. Following the studies of W. Brueggemann and J. Flanagan, the ring structure (ABCCBA) is further compared with other groups of texts in the Samuel corpus. The two lists of soldiers ( 2 Sa. $21: 15-22 ; 23: 8-39$ ) are interpreted by analogy with the double lists of David's sons (2 Sa. 5:13-16, sons born in Jerusalem; 2 Sa. 3:1-5, sons born in Hebron) and ministers (2 Sa. 8:15-18; 20:23-26). When one treats the lists in their double appearance as structural markers, an arrangement very similar to the one in the 'appendix' becomes apparent for 2 Samuel 3-20:

3:1-5 List of sons

3:6-21 David king

3:22-39 Death of Abner

4:1-12 Death of Ishbosheth 21:1-14 Death of Saul's sons

5:1-12 David king I (famine)

5:13-16 List of sons

5:17-25 Victories, Philistines

21:15-22 List, Victors over the Philistines

6:1-23 Ark in Jerusalem

7:1-29 Dynastic Promise

22:1-51 Psalm: Theophany

23:1-10 Last Words: David's dynasty

8:1-14 Victories (all)

8:15-18 List: ministers

23:8-39 List: David's victors (all)

9:1-13 Mephibosheth

10:1-12:31 Sin: murder, adultery 24:1-25 Sin: Census (pestilence)

13:1-19:44 Flight from Absalom (war)

20:1-22 Sheba

\section{0:23-26 List of ministers}

Additionally the two poetic texts (2 Sa. $22 ; 23: 1-7)$ are shown to stand in a complex relationship with the four other songs of the books of Samuel. The allusion to the prophet Gad (2 Sa. 24) belongs in a series of only six encounters between David and prophets, arranged as a set of three pairs: 


$\begin{array}{llll}\text { 1 Sa. 16:13 } & \text { A } & \text { Samuel } & \text { No word or oracle } \\ \text { 1 Sa. 19:18-24 } & \text { A } & \text { Samuel } & \text { No word or oracle } \\ \text { 1 Sa. } 22: 5 & \text { B } & \text { Gad } & \text { Word of salvation } \\ 2 \mathrm{Sa} .7 & \text { C } & \text { Nathan } & \text { Word of salvation } \\ 2 \text { Sa. } 12 & \text { C } & \text { Nathan } & \text { Word of judgment } \\ 2 \text { Sa. } 24 & \text { B } & \text { Gad } & \text { Word of judgment }\end{array}$

The final contrast between the two kings, Saul and David, in the binary opposition of the two narratives (2 Sa. 21:1-14; 24), and the polarity between the rule of Yahweh and sin of the kings, expressed in the tension between centre and periphery, both mirror and finally draw together the main themes of the whole book.

A specific overarching macrostructure for the whole book of Samuel can thus be perceived, which is based not on to linear-chronological principles but according to patterns of parallelism and chiasmus. The chiastic arrangement of the text which is evident in 2 Samuel 21-24 becomes a key to the understanding of the principles of construction which underlie the book as a whole. This observation of a concept of order that is distinct from modern western conventions is further understood, following E. Brunner-Traut, as deriving from an 'aspectival' perception of reality. By means of this kind of reading, many inner relationships open up, linking the closing chapters to the other parts of the book in such a way that it is shown to be a unified literary work.

Building on this view of 2 Samuel 21-24 as an integral part of the Samuel corpus, the third chapter takes a fresh look at the message of the six sections of 2 Samuel 21-24, seeking to understand it as an integrated whole. By this means the most important themes of the book are brought together. The text begins with the depiction of a famine (2 Sa. 21:1-14). The themes of hunger and being filled, eating and drinking frequently recur role throughout Samuel. Food represents the blessing which Yahweh is in a position to bestow, while hunger indicates his anger. The legacy of Saul's legacy reign was a starving people, and this is how the retrospect begins in the Samuel Conclusion. The cause for the famine is said to be a violation of traditional tribal rights. As in the case of Saul's rejection (1 Sa. 15) for not carrying out a ban against the Amalekites, here Saktlss//thictreghterindrg/of ancient covenant 
obligations with respect to the Gibeonites adds a second example of a similar violation, like a second witness justifying David in replacing Saul as king.

The accounts of the four giants in the short episodes in 2 Samuel 21:15-22 show a number of similarities with the much more detailed description of David's victory over Goliath. Taking them together, the total number of conquered Philistine giants adds up to five. The main hostile power in Samuel were the Philistines, organised as a group of five cities, with five princes. They paid tribute to the superiority of Yahweh in the form of presents of gold in sets of five, with the five mice and the five tumours representing the five cities. If the giantconquerors in the finale can be put together with David's maiden victory to form a further group of five which represent the Philistines, then these form an inclusio around the career of David. The conquest of Goliath as David's initial victory, and the overcoming of the four giants as the concluding report in the finale, go together to portray the total overthrow of the all-powerful and frightening enemy with his five kings.

The two poetic pieces in 2 Samuel 22 and 23:1-7 which are placed by the ring-structure at the centre of 2 Samuel 21-24 appear to be of prime importance in determining both the theological tendency of these chapters. David's rule is seen as one which rests upon Yahweh's will and is exercised by his grace. The twofold duty of the king as ruler in righteousness and military commander cannot be undertaken by him independently. The military commander and actual ruler of his people remains Yahweh himself. He deposes priests and kings and chooses others to replace them. The last section (2 Sa. 24), which deals with David's sin, is therefore not to be regarded as accidental. It acts as an unmistakable warning, that the greatness and might of the Davidic empire and the wide extent of its borders must not give rise to self-deception. Yahweh is prepared to maintain his faithfulness to the house of David, but not even a David can reign against the will of Yahweh.

The final chapter summarises the most important results of the preceding interpretation, arguing that the interpretation of Samuel (including 2 Sa. 21-24) as a coherent literary unit may be regarded as at least legitimate if not necessary. 